\title{
Assessing the Impact of Cassava (Manihot Esculenta Crantz), in Nigeria, [A Case Study of 4,000 Farmers Sampled at Different Locations]
}

\author{
Prince Awojoodu Soji \\ Department of Computer Science and Mathematics, Oduduwa University, Ile-Ife Kingdom, Nigeria
}

Email address:

awojoodusoji@yahoo.com

\section{To cite this article:}

Prince Awojoodu Soji. Assessing the Impact of Cassava (Manihot Esculenta Crantz), in Nigeria, [A Case Study of 4,000 FarmersSampled at Different Locations]. Plant. Vol. 7, No. 3, 2019, pp. 33-41. doi: 10.11648/j.plant.20190703.12

Received: July 22, 2019; Accepted: August 15, 2019; Published: August 29, 2019

\begin{abstract}
This research work was carried out, to assess the impact of cassava in Nigeria. 4 Local governments, namely: (Ife East, Ife South, Ife Central and Ife North), local government areas were sampled. 4,000 open questionnaires were distributed to the 4 Local Governments, out of which 1000 was used for the farmers in each local government. A total of 40 different locations were visited in all the four Local Governments, out of which 100 questionnaires were used in each location. It was gathered that above $75 \%$ of the farmers from the four local governments, supported, assessing the impact of cassava in Nigeria. while below $25 \%$ of the farmers, could not even understand whether or not there was any need, to assess the impact of cassava in Nigeria. The results from the questionnaires when using Pearson two-tailed correlation coefficient revealed that there was a significant difference from the summary data collected from the farmers within the four local government areas visited and sampled, $(\mathrm{p}>0.05)$ table 5 . This shows a strong positive correlation, which implying that, to assess the impact of cassava in Nigeria, is strongly influenced and enhanced the farmer's support in our society, and therefore has made the research work to become a reality, $(p>0.05)$ table 5 . The reasons may be due to the fact that, cassava farming is not mainly done, to produce items, solvents, alcohol, glucose, animal feed, energy, fertilizers, and some extra by-products, but many industries in Nigeria also used cassava tubers, as major raw materials for: cassava flour factories, noddles production industries, alcohol and liquor production industries, garri factories, fufu producers etc. Pie chart was used to depict the summary data of each of the local government areas sampled in Ile-Ife Kingdom, of Nigeria.
\end{abstract}

Keywords: Cassava, (Manihot Esculenta Crantz), 4 Local Governments, Different Locations, Pearson Correlation

\section{Introduction}

Cassava (Manihot Esculenta Crantz), of the family Euphorbiaceae, is one type of starchy tuberous; a perennial tree grows in tropical and subtropical areas, which are consumed by the people as a food [1]. Commercial cassava farming has been very profitable farming venture for Nigerian's farmers. Cassava tubers, which is very highlydemanded, as the raw material for producing "GARRI", which is a staplefood for Nigerians.

Cassava farming venture is known forits low input and output nature. Many industries in Nigeria used cassava tubers as major raw materials for: cassava flour factories, noodles production industries, alcohol and liquor production industries, garri factories, fufu producers. Cassava farming is mainly done, to produce items, solvents, alcohol, glucose, animal feed, energy, fertilizers, and some extra by-products. Nigeria tops the list of cassava production list, all over the world while Thailand tops the list of cassava production in the Asian continent. Mainly, from cassava plant, leaves and tubers are the important part, which is used most, by the people for cooking or in other forms. Roots of these commercial crops are mainly consumed because of these, the roots are the excellent source of minerals and vitamins such as manganese, calcium, phosphorus, potassium and iron. All these are responsible for the healthy development of our body. Cassava is among the popular foods grown in Nigeria and has an increasingly diverse use for its product. As a 
result of its uses, cassava farming is becoming lucrative and offers numerous opportunities to would-be investors. Now growing through tropical world, cassava is second onlyto the sweet potatoes, as the most important starchy root crop of the tropics. Because it grows easily, it has large yields and it is little affected by diseases and pest. The area under cassava cultivation is increasing rapidly. The plant is grown for its edible tubers, which serve as a staple food in many tropical countries and are also the source of an important starch. Its value is a famine relief crop has long been recognized. Cassava is now grown widely as a food crop or for industrial purposes. In many regions of the tropics, cassava occupies much the same position as sweet potatoes do in some parts of the temperate zone as the principal carbohydrate of the daily diet. The industrial utilization of cassava is expanding every year. The plant is popularly known under a great variety of names: In Yoruba speaking people of Nigeria, It is called EGE or GBAGUDA. In Indonesia, it is called UBI KETTELA or KASPE. In Latin America, it is called MANIOCA, RUMU or YUCCA. In Brazil, it is called MANDOCA or AIPIM. In Madagasca and French Speaking Africa, it is called MANIOC. In India and Malaysia, it is called TAPIOCA. In English speaking regions in Africa, Thailand, Srilanka. It is called CASSAVA and sometimes CASSADA ON HARVEST: For high quality of cassava, for both short term and long term spoilage before harvest and storage, cassava should be protected from healthy stem cutting that helps to reduce the spread of cassava pests, and diseases. There are some risks connected, in growing cassava. This is because, in Nigeria and other African countries, cassava plant is not normally affected by diseases or pests. However, in others, it may be attracted by VIRUS DISEASES, like: (a). mosaic. (b). the brown streak and leaf curl of tobacco may attack leaves, stems and branches. Many parts of Africa harbour these diseasesand attempts are being made to select resistant varieties. BACTERIA DISEASES, like: phytomonasmanihotis (in Brazil), Becterium cassava (in Africa), and Bacterium solanacearum (in Indonesia), may attack roots, stems or leaves of cassava plants. MYCOSES: There kinds which attack roots, stem or leaves of cassava plants and cause various diseases. INSECTS: Some insects affect the plant directly (locusts, beetles, and ants). Others affect the plant indirectly by the transfer of virus (aphids). ANIMALS, like rats, goats, and wild pigs are probably the most troublesome, they freed on the roots, especially in areas adjacent to forests. TOXICITY: The toxicity principle in cassava is hydrocyanic acid, found in the roots, branches and leaves of the plant in both free and chemically bound forms. The plant contains a cyanogenetic glucose called phaseolunatin. This begins to break down upon cassava harvest into hydrocyanic acid, acetone and glucose by the action of the enzyme linase. The presence of hydrocyanic acid is easily recognized by a bitter taste, [2]. At the harvest of cassava roots, the amount of the acid in the plant varies from harmless to lethal; from a few milligrams to 250 milligrams or more per kilogram of fresh root. Hydrolysis of the glucose by the enzyme can be accelerated by soaking the root in water, by crushing or cutting them or by heating. The distribution of the acid in roots varied in different varieties. In sweet varieties, the major of the acid is located in the skin and in the exterior cortical layer, while in bitter varieties; the acid is uniformly distributed in all parts of the roots, [3]. PREPARATION METHODS: The selected stem cutting should be planted the right way by ensuring that the land was appropriate tilled. The planting season, the type of seed bed, preparation methods, handling and planting of the stem cutting, should be done with precision. Cassava tubers attached to the main stem can remain safely in the ground for several months. However, after harvest, the roots start deteriorating within 2-3 days, and rapidly become of little value for consumption or industrial use. When storing, cassava roots as earlier said, start deteriorating, soon after harvesting, but internally discoloration and loss of marketing value occur if they are not cooked or processed within 24-48 hours of harvesting. Secondary fungi, and bacteria infection may cause rot in untreated roots. It was however noted from the traditional methods of storage that, cassava roots are heaped under shade and watered every day; the roots may be coated with clay and mud; freshly harvested or peeled roots are stored for 1-2 days by completely submerging in water. The roots are simultaneously detoxified but may ferment or spoilt after 3 days; cassava roots are left underground after maturity and harvest in piecemeal when needed, etc.
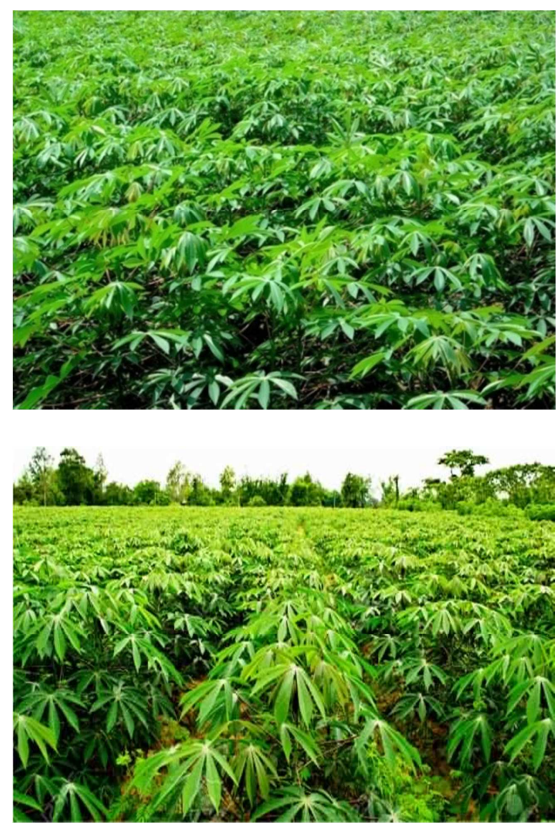

Figure 1. Cassava (Manihot esculenta Crantz), of the family Euphorbiaceae.

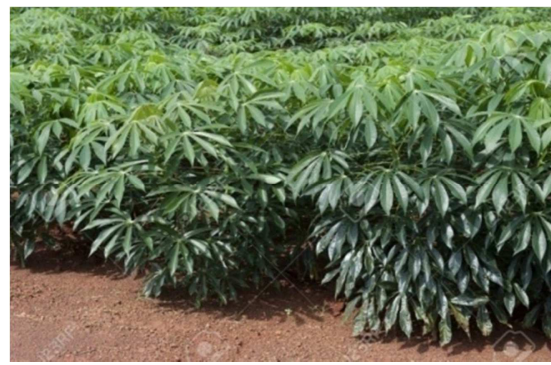




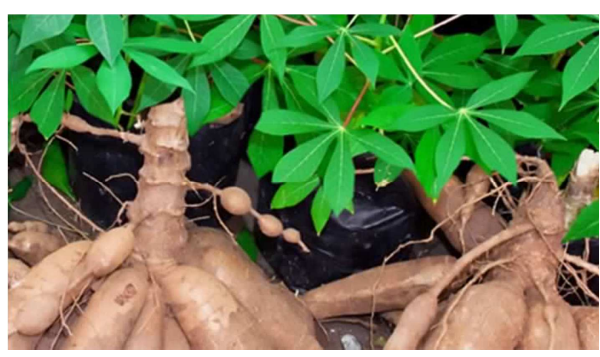

Figure 2. Cassava History/Origin.

ORIGIN: The centre of its origin wasbelieved to be traced to the old World War before the discovery of America. There is archaeological evidence of two major centers of origin for this crop; onein Mexico and central America and the other in north eastern Brazil. The first Portuguese settlers found the native Indian in Brazil, growing the cassava plant. And that the "poisonous root" of a yucca was used in the preparation of bread, [4]. It is believed that cassava was introduced to the western coast of Africa in about the sixteen century by slave merchants. The Portuguese bought it later to their stations around the month of the Congo River, and it then spread to other area. The preparation of cassava flour in Angola and subsequently its uses in the Congo. The cassava cultivation increased after 1850 in the east African territories as a result of the efforts of Europeans and Arabs who were pushing into the interior and who recognized itsvalue as a safeguard against the frequent period of time [5]. In the Far East, cassava was not known as a food plant until 1835. In about 1850 , it was transported directly from Brazil to Java, Singapore and Malaya. When the more profitable rubber plantation were started on theMalaya Peninsula, cassava as the mostimportant growing, movedto other parts of Indonesia where it flourished, [6].

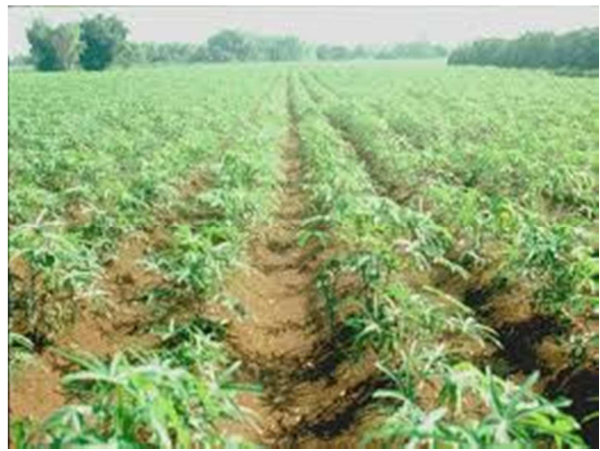

Figure 3. Cassavayears of maturity.

MONTHS AND PERIODS OF MATURITY OF CASSAVA (MANIHOT ESCULENTA CRANTZ), IN NIGERIA: The plant produces best when rainfall is fairly abundant, but it can be grown where annual rainfall is low as
$500 \mathrm{~mm}$ or where it is as high as $5000 \mathrm{~mm}$. The plant can stand prolonged periods of drought in which most other food crops would perish. This makes it valuable in regions where annual rainfall is low or where seasonal distribution is irregular. In tropical climate, the dry season has about the same effect on cassava as low temperature has on deciduous perennials in other parts of the world. The period of dormancy lasts two to three months and growth resumes when the rain begins again.

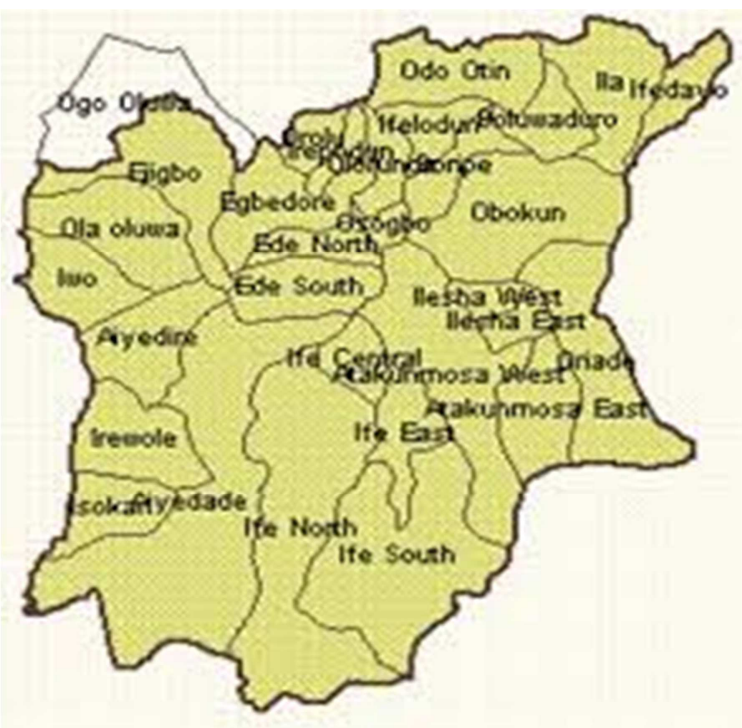

Figure 4. Study Area Map of Ife (Known as Ile-Ife).

\section{Study Area}

The study area is Ife. Ife (popularly known as Ile-Ife) is the $2^{\text {nd }}$ largest city in Osun State and has been selected for the proposed research work. Ife is an ancient Yoruba city in South Western Nigeria. The city is located in present day of Osun State. Ile - Ife is famous Worldwide for its ancient and naturalistic bronze, stone and terracotta sculptures dating back to between 1200 and 1400. It has a population of 262,000 (1991 population estimate). The city is the oldest Yoruba city in South WesternNigeria and evidence of habitation at the site has been discovered to date-back to as early as $600 \mathrm{BCE}$. The city was the most powerful Yoruba Kingdom until the late $17^{\text {th }}$ century when Oyo surpassed it. (Encyclopedia Britannica).

\section{Material and Methods}

The responses of the people in different locations of the four local government areas can be seen from the decision table as below:

Table 1. TheDecision Table.

\begin{tabular}{llll}
\hline Sub & Above 75\% & Below 25\% & Open headed Questionnaires \\
\hline Assessing the impact of cassava in Osun State, Nigeria. & $\mathrm{X}$ & $\mathrm{X}$ \\
I do not know & & $\mathrm{X}$ \\
State open questionnaires & & \\
\hline
\end{tabular}


The below are the points ticked by the majority of the people (above $75 \%$ table 1) from the questionnaires who understood, assessingthe impact of cassava in Osun State, Nigeria.:[a]. Cassava is helpful in boosting the immune system and lowering the blood pressure. [b]. Consuming cassava frequently is also beneficial for good nerve and brain health. [c]. Cassava is also rich in fibers and dietary. Fibers are helpful in preventing constipation. [d]. Consuming cassava is also beneficiary for good eye health, hair health and skin health. [e]. cassava also contains a high amount of carbohydrates content in them, so, consuming cassava can provide lots of energy to our body. [f]. Consuming cassava is helpful in weight management. [g]. Eating cassava regularly prevents you from many types of cancer and also enhance the good digestive system. [h]. Cassava also helps in treating diarrhea, and the rheumatic diseases. [i]. cassava is also used as home remedy for curing headaches and fever. It also heals the wound faster. [j]. Cassava regulates blood pressure: the potassium, magnesium, and calcium contents help in regulating human body pressure. [k]. Lack of potassium can lead to a depletion of calcium in bones. [1]. Potassium found in cassava help not only to lower pressure, but thereby protecting the human body against stroke. [m]. Cassava prevent cold: vitamin c, that is antioxidant and antiinflammatory, helps to relieve cold symptoms. [n]. Cassava fight health diseases and diabetes.

\section{Results and Discussion}

Questionnaires were distributed to 4 Local government areas that is, (Ife East, Ife South, Ife Central and Ife North). The results from the questionnaires however revealed that, assessing the impact of cassava in Nigeria are manifold: There was a significant difference on the farmers, in all the local government areas visited, $(\mathrm{p}>0.05)$.

Table2. People's respondent.

\begin{tabular}{|c|c|c|c|c|c|c|c|c|}
\hline & Ife East & & Ife South & & Ife Central & & Ife North & \\
\hline Wards & $\begin{array}{l}\text { Assessing the } \\
\text { impact of cassava in } \\
\text { Osun State, Nigeria. }\end{array}$ & $\begin{array}{l}\text { I do not } \\
\text { Know }\end{array}$ & $\begin{array}{l}\text { Assessing the impact } \\
\text { of cassava in Osun } \\
\text { State, Nigeria. }\end{array}$ & $\begin{array}{l}\text { I do not } \\
\text { Know }\end{array}$ & $\begin{array}{l}\text { Assessing the impact } \\
\text { of cassava in Osun } \\
\text { State, Nigeria. }\end{array}$ & $\begin{array}{l}\text { I do not } \\
\text { Know }\end{array}$ & $\begin{array}{l}\text { Assessing the impact } \\
\text { of cassava in Osun } \\
\text { State, Nigeria. }\end{array}$ & $\begin{array}{l}\text { I do not } \\
\text { Know }\end{array}$ \\
\hline $\begin{array}{l}\text { People's } \\
\text { Response }\end{array}$ & $70170.1 \%$ & $\begin{array}{l}29929.9 \\
\%\end{array}$ & $69769.7 \%$ & $\begin{array}{l}303 \\
30.3 \%\end{array}$ & $66566.5 \%$ & $33533.5 \%$ & $66866.8 \%$ & $33233.2 \%$ \\
\hline
\end{tabular}

From the above table 2, in Ife East, there are 701 people's response with $70.1 \%$, Ife South, 697 with $69.7 \%$, Ife Central, 655 with $65.5 \%$, and Ife North, 668 with $66.8 \%$, were those people who supported, assessing the impact of cassava in Osun State, Nigeria, while in Ife East, 299 with $29.9 \%$, Ife
South, 303 with $30.3 \%$, Ife Central, 335 with $33.5 \%$, and Ife North, 332 with $33.2 \%$ respectively, could not even know whether or not, there was any assessment on the impact of cassava in Osun State, Nigeria.

Table 3. The summary data collected, from the 4 Local Governments sampled, out of which 900 were used in each local government.

\begin{tabular}{|c|c|c|c|c|c|c|c|c|c|}
\hline \multirow[t]{2}{*}{ Local government } & \multirow{2}{*}{$\begin{array}{l}\text { Location } \\
\text { A }\end{array}$} & \multicolumn{2}{|c|}{ Ife East } & \multicolumn{2}{|c|}{ Ife South } & \multicolumn{2}{|c|}{ Ife Central } & \multicolumn{2}{|c|}{ Ife North } \\
\hline & & 72 & 28 & 68 & 32 & 52 & 48 & 58 & 42 \\
\hline \multirow{7}{*}{ Peoples Respondent } & $\mathrm{B}$ & 70 & 30 & 62 & 38 & 59 & 41 & 69 & 31 \\
\hline & $\mathrm{D}$ & 64 & 36 & 65 & 35 & 68 & 32 & 66 & 34 \\
\hline & $\mathrm{E}$ & 76 & 24 & 66 & 34 & 74 & 26 & 62 & 38 \\
\hline & $\mathrm{F}$ & 75 & 25 & 68 & 32 & 76 & 24 & 74 & 26 \\
\hline & $\mathrm{H}$ & 67 & 33 & 72 & 28 & 62 & 38 & 63 & 37 \\
\hline & I & 74 & 26 & 74 & 26 & 65 & 35 & 64 & 36 \\
\hline & $\mathrm{J}$ & 78 & 22 & 70 & 30 & 73 & 27 & 71 & 29 \\
\hline Total $=$ & 10 & 701 & 299 & 697 & 303 & 665 & 335 & 668 & 332 \\
\hline Grand Total $=$ & 10 & 1000 & & 1000 & & 1000 & & 1000 & \\
\hline
\end{tabular}

Table 4. The descriptive statistics.

\begin{tabular}{llll}
\hline Descriptive Statistics & & & N \\
\hline & Mean & Std. Deviation & 10 \\
\hline IFEEAST & 70.1000 & 5.80134 & 10 \\
IFESOUTH & 69.7000 & 4.85455 & 10 \\
IFECENTRAL & 66.5000 & 8.72098 & 10 \\
IFENORTH & 66.8000 & 5.63323 & 10 \\
\hline
\end{tabular}


Table 5. Pearson Correlation.

\begin{tabular}{llllll}
\hline Correlations & & & & & \\
\hline & & IfeEast & IfeSouth & IfeCentral & IfeNorth \\
\hline \multirow{3}{*}{ IFEEAST } & Pearson Correlation & 1 & -338 & 223 & -074 \\
& Sig. (2-tailed) & & 339 & 536 & 839 \\
& $\mathrm{~N}$ & 10 & 10 & 10 & 10 \\
IFESOUTH & Pearson Correlation & -338 & 1 & 198 & 229 \\
& Sig. (2-tailed) & 339 & & 583 & 524 \\
& $\mathrm{~N}$ & 10 & 10 & 10 & 10 \\
IFECENTRAL & Pearson Correlation & 223 & 198 & 1 & 023 \\
& Sig. (2-tailed) & 536 & 583 & 10 & 10 \\
IFENORTH & $\mathrm{N}$ & 10 & 10 & $706^{*}$ & 1 \\
& Pearson Correlation & 074 & 229 & 023 & 10 \\
\hline
\end{tabular}

*. Correlation is significant at the 0.05 level (2-tailed).

FREQUENCIES VARIABLES=IFEEAST IFESOUTH IFECENTRAL IFENORTH

/NTILES $=4$

/NTILES $=10$

/STATISTICS=STDDEV VARIANCE RANGE MINIMUM MAXIMUM SEMEAN MEAN MEDIAN MODE SUM SKEWNESS SESKEW

KURTOSIS SEKURT

/GROUPED=IFEEAST IFESOUTH IFECENTRAL IFENORTH

/PIECHART PERCENT

/ORDER=ANALYSIS.

Frequencies

Table 6. The mode, median, mean, std. Deviation etc., ofthe4 local governments.

\begin{tabular}{|c|c|c|c|c|c|}
\hline \multicolumn{6}{|l|}{ Statistics } \\
\hline & & IFEEAST & IFESOUTH & IFECENTRAL & IFENORTH \\
\hline \multirow{2}{*}{$\mathrm{N}$} & Valid & 10 & 10 & 10 & 10 \\
\hline & Missing & 0 & 0 & 0 & 0 \\
\hline \multicolumn{2}{|l|}{ Mean } & 70.1000 & 69.7000 & 66.5000 & 66.8000 \\
\hline \multicolumn{2}{|c|}{ Std. Error of Mean } & 1.83455 & 1.53514 & 2.75782 & 1.78139 \\
\hline \multicolumn{2}{|c|}{ Median } & $71.0000^{\mathrm{a}}$ & $69.3333^{\mathrm{a}}$ & $66.5000^{\mathrm{a}}$ & $65.5000^{\mathrm{a}}$ \\
\hline \multicolumn{2}{|l|}{ Mode } & $62.00^{\mathrm{b}}$ & $68.00^{\mathrm{b}}$ & $52.00^{\mathrm{b}}$ & $58.00^{\mathrm{b}}$ \\
\hline \multicolumn{2}{|c|}{ Std. Deviation } & 5.80134 & 4.85455 & 8.72098 & 5.63323 \\
\hline \multicolumn{2}{|c|}{ Variance } & 33.656 & 23.567 & 76.056 & 31.733 \\
\hline \multicolumn{2}{|l|}{ Skewness } & -188 & 148 & -231 & 281 \\
\hline \multicolumn{2}{|c|}{ Std. Error of Skewness } & 687 & 687 & 687 & 687 \\
\hline \multicolumn{2}{|c|}{ Kurtosis } & -1.593 & -541 & -1.185 & -656 \\
\hline \multicolumn{2}{|c|}{ Std. Error of Kurtosis } & 1.334 & 1.334 & 1.334 & 1.334 \\
\hline \multicolumn{2}{|c|}{ Range } & 16.00 & 16.00 & 26.00 & 18.00 \\
\hline \multicolumn{2}{|l|}{ Minimum } & 62.00 & 62.00 & 52.00 & 58.00 \\
\hline \multicolumn{2}{|l|}{ Maximum } & 78.00 & 78.00 & 78.00 & 76.00 \\
\hline \multicolumn{2}{|l|}{ Sum } & 701.00 & 697.00 & 665.00 & 668.00 \\
\hline \multirow{11}{*}{ Percentiles } & 10 & $62.5000^{c}$ & $63.5000^{c}$ & $55.0000^{\mathrm{c}}$ & $60.0000^{c}$ \\
\hline & 20 & 63.5000 & 65.5000 & 58.5000 & 62.5000 \\
\hline & 25 & 64.0000 & 66.0000 & 59.0000 & 63.0000 \\
\hline & 30 & 65.5000 & 66.6667 & 60.5000 & 63.5000 \\
\hline & 40 & 68.5000 & 68.0000 & 63.5000 & 64.5000 \\
\hline & 50 & 71.0000 & 69.3333 & 66.5000 & 65.5000 \\
\hline & 60 & 73.0000 & 71.0000 & 70.5000 & 67.5000 \\
\hline & 70 & 74.5000 & 72.6667 & 73.5000 & 70.0000 \\
\hline & 75 & 75.0000 & 73.3333 & 74.0000 & 71.0000 \\
\hline & 80 & 75.5000 & 74.0000 & 75.0000 & 72.5000 \\
\hline & 90 & 77.0000 & 76.6667 & 77.0000 & 75.0000 \\
\hline
\end{tabular}

a. Calculated from grouped data.

b. Multiple modes exist. The smallest value is shown.

c. Percentiles are calculated from grouped data. 
Frequency Table

Tables $(7,8,9,10)$ showing the frequency Tables of all the 4 (four) Local Government Areas sampled.

Table 7. Thevalid and cumulative \% of Ife East.

\begin{tabular}{|c|c|c|c|c|c|}
\hline \multicolumn{6}{|c|}{ IfeEast } \\
\hline & & Frequency & Percent & Valid Percent & Cumulative Percent \\
\hline \multirow{11}{*}{ Valid } & 62.00 & 1 & 10.0 & 10.0 & 10.0 \\
\hline & 63.00 & 1 & 10.0 & 10.0 & 20.0 \\
\hline & 64.00 & 1 & 10.0 & 10.0 & 30.0 \\
\hline & 67.00 & 1 & 10.0 & 10.0 & 40.0 \\
\hline & 70.00 & 1 & 10.0 & 10.0 & 50.0 \\
\hline & 72.00 & 1 & 10.0 & 10.0 & 60.0 \\
\hline & 74.00 & 1 & 10.0 & 10.0 & 70.0 \\
\hline & 75.00 & 1 & 10.0 & 10.0 & 80.0 \\
\hline & 76.00 & 1 & 10.0 & 10.0 & 90.0 \\
\hline & 78.00 & 1 & 10.0 & 10.0 & 100.0 \\
\hline & Total & 10 & 100.0 & 100.0 & \\
\hline
\end{tabular}

Table 8. Thevalid and cumulative \% of Ife South.

\begin{tabular}{|c|c|c|c|c|c|}
\hline \multicolumn{6}{|c|}{ Ife South } \\
\hline & & Frequency & Percent & Valid Percent & Cumulative Percent \\
\hline \multirow{11}{*}{ Valid } & 62.00 & 1 & 10.0 & 10.0 & 10.0 \\
\hline & 63.00 & 1 & 10.0 & 10.0 & 20.0 \\
\hline & 64.00 & 1 & 10.0 & 10.0 & 30.0 \\
\hline & 67.00 & 1 & 10.0 & 10.0 & 40.0 \\
\hline & 70.00 & 1 & 10.0 & 10.0 & 50.0 \\
\hline & 72.00 & 1 & 10.0 & 10.0 & 60.0 \\
\hline & 74.00 & 1 & 10.0 & 10.0 & 70.0 \\
\hline & 75.00 & 1 & 10.0 & 10.0 & 80.0 \\
\hline & 76.00 & 1 & 10.0 & 10.0 & 90.0 \\
\hline & 78.00 & 1 & 10.0 & 10.0 & 100.0 \\
\hline & Total & 10 & 100.0 & 100.0 & \\
\hline
\end{tabular}

Table 9. Thevalid and cumulative \% of IfeCentral.

\begin{tabular}{|c|c|c|c|c|c|}
\hline \multicolumn{6}{|c|}{ IfeCentral } \\
\hline & & Frequency & Percent & Valid Percent & Cumulative Percent \\
\hline \multirow{11}{*}{ Valid } & 52.00 & 1 & 10.0 & 10.0 & 10.0 \\
\hline & 58.00 & 1 & 10.0 & 10.0 & 20.0 \\
\hline & 59.00 & 1 & 10.0 & 10.0 & 30.0 \\
\hline & 62.00 & 1 & 10.0 & 10.0 & 40.0 \\
\hline & 65.00 & 1 & 10.0 & 10.0 & 50.0 \\
\hline & 68.00 & 1 & 10.0 & 10.0 & 60.0 \\
\hline & 73.00 & 1 & 10.0 & 10.0 & 70.0 \\
\hline & 74.00 & 1 & 10.0 & 10.0 & 80.0 \\
\hline & 76.00 & 1 & 10.0 & 10.0 & 90.0 \\
\hline & 78.00 & 1 & 10.0 & 10.0 & 100.0 \\
\hline & Total & 10 & 100.0 & 100.0 & \\
\hline
\end{tabular}

Table 10. Thevalid and cumulative \% of IfeNorth.

\begin{tabular}{llllll}
\hline IfeNorth & & & & & \\
\hline \multirow{6}{*}{ Valid } & & Frequency & Percent & Valid Percent & Cumulative Percent \\
\hline & 58.00 & 1 & 10.0 & 10.0 & 10.0 \\
& 62.00 & 1 & 10.0 & 10.0 & 20.0 \\
& 63.00 & 1 & 10.0 & 10.0 & 30.0 \\
& 64.00 & 1 & 10.0 & 10.0 & 40.0 \\
& 65.00 & 1 & 10.0 & 10.0 & 50.0 \\
& 66.00 & 1 & 10.0 & 10.0 & 70.0 \\
& 69.00 & 1 & 10.0 & 10.0 & 80.0 \\
& 71.00 & 1 & 10.0 & 10.0 & 90.0 \\
& 74.00 & 1 & 10.0 & 10.0 & 100.0 \\
\hline
\end{tabular}


Figures (5, 6, 7 and 8). The Pie Chart, of all the (4) four Local Government sampled.

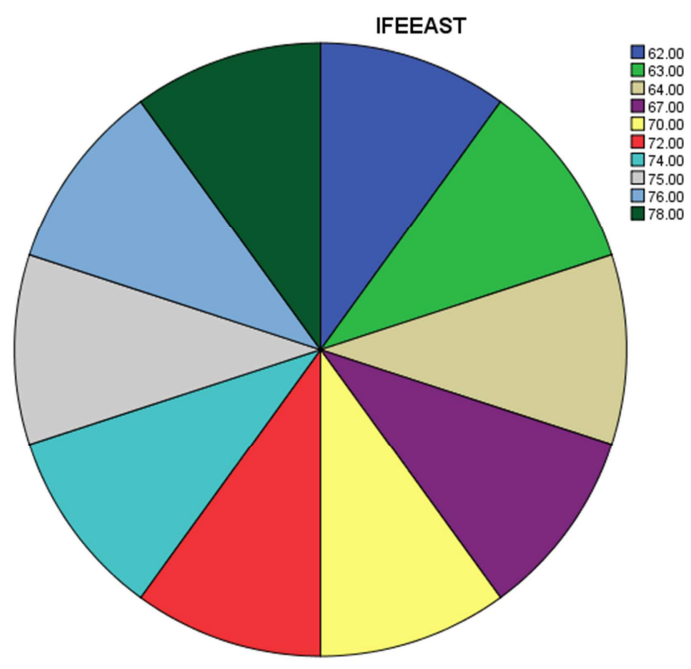

Figure 5. The Piechart of Ife East.

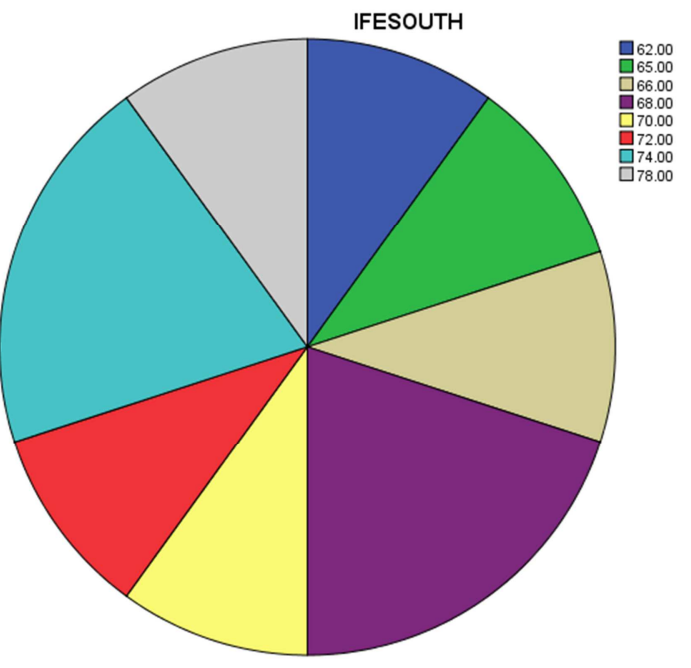

Figure 6. The Pie chart of Ife South.

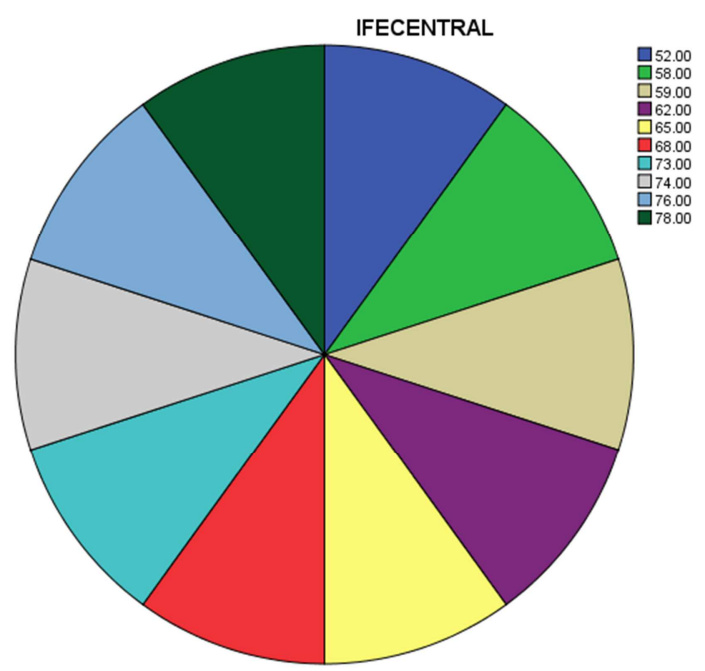

Figure 7. The Pie chart of Ife Central.

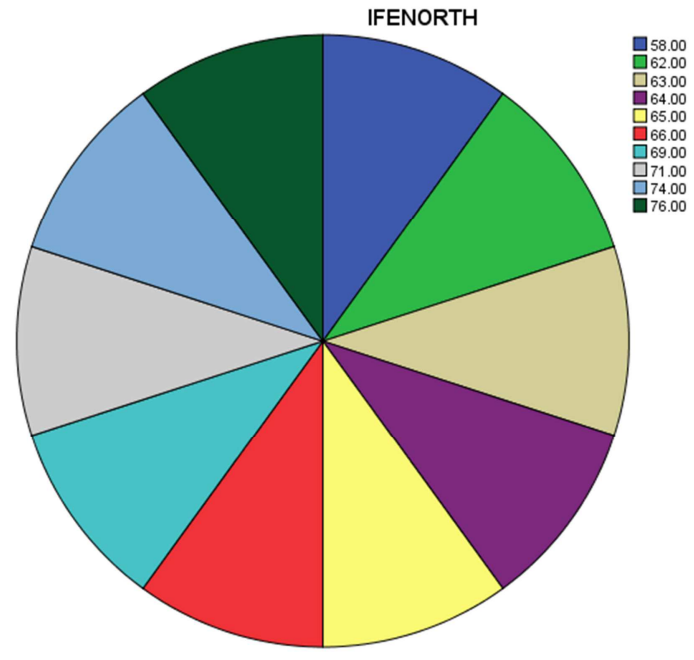

Figure 8. The Pie chart of Ife North.

\section{Recommendations}

1. For high Productivity and ultimate high investment, the Federal Government of Nigeria should encouraged cassava farmers to make research and seek expert opinion and advice for the latest productivity techniques to maximize profit.

2. Workshop at different intervals should be organized to farmers, so as to educate them in the uses of current farmer's equipments, to increase their cassava output production and eradicate cassava spoilage.

3. Some of the rural areas roads in, Nigeria are bad. Government should provide good motor-able roads to farmers in plantation areas with high concentration of cassava farm.

4. Nigerian Government should encourage cassava plantation, by given funds/loans to prospective investors.

5. Federal government should support the farmers by given enough assistance in terms of cassava roots subsidy, so as to booth their production.

6. Government should organized Agricultural extension services to farmers by providing and bringing agricultural equipments closer to them, so as to reduce the cost of cassava harvest to the buyers.

7. Government should provide electricity in rural areas for Farmers to enable them to stay longer in their farm for maximum increase in their cassava harvest Production.

8. Government should erect large storage facilities at intervals for cassava farmers, to avoid losses and spoilage.

\section{Conclusion}

The following conclusions are made based on the findings of this study. Since, many industries in Nigeria 
used cassava tubers astheirmajor raw materials for: cassava flour factories, noddles production industries, alcohol and liquor production industries, garri factories, fufu producers, and also, roots of these commercial crops are mainly consumed because, these roots are the excellent source of minerals and vitamins such as manganese, calcium, phosphorus, potassium and iron, also, all these are responsible for the healthy development of our body, the results of this study provide the empirical evidence that, assessing the impact of cassava in Nigeria, had enhanced people's achievement in our society. The society, therefore should use, assessing the impact of cassava in Nigeria, to argument peoples' maximal output in their businesses, in order to attain minimum goal needed for everybody in the society.

\section{Acknowledgements}

The Author wishes to express his appreciations to all especially those whose papers that are shown in my references to provide the premise for this study, and Dr./Chief Ramond Adedoyin, (The ATOBATELE, and MAYE of Yoruba Kingdom), The Chancellor and Founder of Oduduwa University for providing the fund and space to carry out this research work/study.

\section{References}

[1] Aderinlewo E. O., 1982. Basic Secondary Science Book 1. Published by Evans Brothers Limited. Montague House, Russell square London WC1B5BX. Composition in 11on 13point century by Film type services Limited, Scarborough, North Yorkshire and Printed by William Clowes (Beccles) Limited, Beccles and London ISBN0237505274. NPR 1137.

[2] Ashutosh Kar, 2011. Advanced Practical Chemistry. First Edition. Printed in India at Saras Graphics, Rai, Haryana. Typeset at Goswami Associates, Delhi. Publishing for one world. New Age International (P) Limited, Publishers. 4835/24, Ansari Road, Daryaganj, New Delhi-110002. ISBN (0): 81-224-1539-9. ISBN (13): 978-81-224-1539-1.

[3] Dr. Tilak Ram, 2013. Food Chemistry. Published in India by Random Publications. 4376-A/4B. Gall Murari Lai, Ansari Road, New Delhi- 110002. Typesetting by: Friends Media, Delhi- 110087. Digitally Printed at: Replica Press Pvt. Ltd. ISBN978-93-5111-032-3.

[4] Elservier, E. [2009. Guide to Protein Purification. 2nd Edition. Academic Press. 525B street, suite 1900. San Diego, a 921014495, USA, 30 corporate Drive. Suite 400, Burlington, MA 01803, USA. 32 Jamestown Road, London. NW1 7BY, UK. ISBN: 978-0-12-374536-1 (hardback). ISBN: 978-0-12374978-9 (paper back). ISSN: 0076-6879.

[5] Fan Y. Ding Z. Yang L. et al. A Preliminary Study on Bioactivity of Orange and Tangerine Peal extracts against Apluis and mites. Zhongguo Zhong Yao ZaZhi 1995 Jul: 20 (7): 397-8, 446. 1995. PMID: 13090.

[6] George Coulouris, Jean Dollimore and Tim Kindberg, 2011. Distributed Systems, Concepts and Design, 4th Edition. Published by Dorling Kindersley [India] Pvt. Ltd. Licensees of Pearson Education in South Asia. Head Office: 7th floor,
Knowledge Bouleward. A-8 [A], Sector-62. Noida-201309, U. P. India Registered Office: 11 Community Centre, Panchsheel Park. New Delhi 110017, India. Printed in India by Manipal Press Ltd. ISBN978-81-317-1840-7. Authorized adaptation from the United Kingdom Edition, Entitled Distributed System Concepts and Design. Forth Edition, ISBN: 9780321263544 by Coulouris, George: Dollimore, Jean; Kindberg, Tim; Published by Education, Ltd.Copyright@2005. IndianSubcontinent Adaptation copyright@2009 Dorling Kindersley [India] Pvt. Ltd.

[7] Gordon M. Wardlaw, 2003. Contemporary Nutrition Issues and Insight. Fifth Edition. Published by Mc Graw-hill, a business unit of McGraw-Hill Companies, Inc., 1221avenue of the Americas, New York, NY 10020. ISBN: 0-07-286530X. ISBN: 0-07-119903-X (15E). International Edition. ISBN: 0-07-118808-X.

[8] Honow R., Laube N. Schneider A, Kessier T. Hesser. Influence of grape fruit, Orange, and applejuice consumption on urinary variables and risk of crystallization. Br. Intr. Aug: 90 (2) 295-300. 2003. PMID: 12908889.

[9] Jill Norman, 1997. The Classic Herb Cook Book. First published in Great Britain by Dorling Kindersley Limited. 9, Henrietta Street, London WC2E8PS. Reprint in 1997. ACIP for this book is available from the British Library. ISBN: 0751303232. Reproduced in Italy by Scanner Service SRL. Printed and bound in Italy by a Monadori, Veronica.

[10] John R. Holum, 1975. Experiments in General Organic and Biological Chemistry. A laboratory Manual, Forth Edition. New York. London. Sydney. Toronto. Printed in the United State of America. 10987654321.

[11] Kumar R., 1984. Insect Pest Control. First Published in Great Britain. Printed and bound in Great Britain by Atheneum Press Ltd. Gates head British Library Cataloguing in Publication Data. ISBN 0713180838. Member of the Holder Headline Group. 338EustonRoad, London WW1 3BH.

[12] Melvin Calvin and J. A Bassham1962. The Photosynthesis of Carbon Compounds. Library of Congress Catalogue Card Number: 62-10567. Manufactured in the United States of America. The Manuscripts was received November 15, 1961, and Published February 27, 1962. W. A. Benjamin, Inc. 2465 Broadway, New York 25, New York.

[13] Nyle C. Brandy, 1990. The natureand Properties of Soils. Printed in the United State of America by Mac Millian Publishing Company. Simon \& Schuster A. Viacon Company, Upper Saddle River, New Jersey, 074p58. ISBN 0-13-852-444-0.

[14] O. P. Agarwal, 2014. Organic Chemistry, Natural Products Volume- 1. Published by: Satyendra Rostogi, "mitra" for KRISHNA Prakasha media (P) Ltd. 11, Shivaji Road, Meerut25001 (U. P.) India. Printed at Majmoon Press, Meerut. Typing: DEBUGCC. (The computer concern) Ghaziabad, ISBN: 978-81-8283-556-6.

[15] Rai H., 2004. Basic Industrial Biochemistry. Printed in India at Ramprintograph, Delhi. Typeset at In-house. Publishing for one world. New Age International (P) limited. Publishers. 4835/24, Ansari Road, Daryaganj, New Delhi-110002. ISBN: 978- 81-224-3404-0.\} 295. C-12-04-6261.

[16] Rapisarda P. Tomaino A. Lo Cascio R., et al. Antroxidant effectiveness as influenced by Phenoliccontent of fresh orange juices. J, Agric Food Chem. 1999 Nov: 47 (11): 4718-231999. PMID: 13080. 
[17] S. K. Jain, 2001. Mineral Processing. For CBS Publishers and Distributors Pvt. Ltd. CBSPlaza, 4819/XIPrahlad Street, 24 Ansari Road, Daryaganj, New Delhi- 110002, India. Ph: 23289259, 232668861, 23266867. ISBN: 81-239-0753-2.
[18] Tilak Wasan, 2015. Solid Waste Pollution and Health. Published at Arisari Road, 4383/4B, Darga Ganj. New Delhi110002 (India). ISBN: 978-93-5056-306-9. Discovery Publishing House PVT. Ltd. Printed at: Infinity Imaging Systems Delhi. 